\title{
THICKNESS AND CROSS-SECTIONAL AREA OF THE ACHILLES TENDON IN MARATHON RUNNERS: A CROSS-SECTIONAL STUDY
}

\author{
ESPESSURA E ÁREA TRANSVERSAL DO TENDÃO DE AQUILESEM MARATONISTAS: UM ESTUDO
}

ARTIGO ORIGINAL Artículo Original

TRANSVERSAL

\section{ESPESOR Y ÁREA TRANSVERSAL DEL TENDÓN DEAQUILES EN MARATONISTAS: UN ESTUDIO TRANSVERSAL}

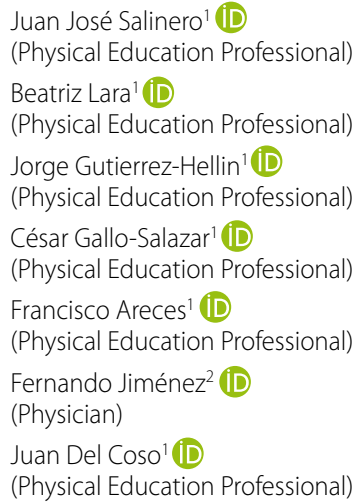

1. Universidad Camilo José Cela. Physiology and Exercise Laboratory. Madrid, Spain. 2. Universidad de Castilla-La Mancha. Sports Performance and Readaptation Laboratory, Toledo, Spain.

\section{Correspondence:}

Juan Del Coso.

Castillo de Alarcon, 49, Villafranca del Castillo, 28692, Spain.

juan.delcoso@urjc.es

\begin{abstract}
Introduction: This study aimed to measure thickness and cross-sectional area of the Achilles tendon (AT), and the range of motion of the ankle joint in dorsiflexion of amateur marathon runners compared to non-active people. Objectives: To analyze the relationship between cross-sectional area and thickness of the Achilles tendon in marathon runners and age, anthropometric characteristics (height and body mass), training habits, running experience, marathon performance, and range of motion in the ankle joint. Methods: Achilles tendon thickness and cross-sectional area were measured using ultrasound images of the left leg in 97 male amateur marathon runners (age $42.0 \pm 9.6$ years; height $175 \pm 6 \mathrm{~cm}$; and body mass $73.7 \pm 8.6 \mathrm{~kg}$ ), and 47 controls $(39.9 \pm 11.6$ years; $176 \pm 7 \mathrm{~cm} ; 79.6 \pm 16.1 \mathrm{~kg})$. Results: Achilles tendon thickness $(4.81 \pm 0.77 \mathrm{vs} .4 .60 \pm 0.66 \mathrm{~mm}$; $p=0.01)$ and cross-sectional area $\left(60.41 \pm 14.36 \mathrm{vs} .53 .62 \pm 9.90 \mathrm{~mm}^{2} ; p<0.01\right)$ were greater in the marathon runners than in non-active people. Achilles tendon thickness has been correlated, in a weak but significant manner, with years of running experience. Moreover, marathon runners showed increased ankle range of motion $(81.81 \pm 6.93$ vs. $77.86 \pm 7.27$ grades; $p<0.01$ ). Conclusion: Male amateur marathon runners have hypertrophy of the Achilles tendon compared to non-active people, and this enlargement is mediated by running experience. In addition, range of motion in ankle dorsiflexion is favored by marathon training. Level of evidence III; Retrospective study.
\end{abstract}

Keywords: Running; Tendons; Achilles tendon; Range of motion.

\section{RESUMO}

Introdução: Este estudo visou medir a espessura e a área transversal do tendão de Aquiles (TA) e a amplitude de movimento da articulação do tornozelo em flexão dorsal em maratonistas amadores, em comparação com indivíduos não ativos. Objetivos: Analisar a relação entre a área transversal e a espessura do tendão de Aquiles em maratonistas eidade, características antropométricas (estatura e massa corporal), hábitos de treinamento, experiência de corrida, desempenho em maratona e amplitude de movimento da articulação do tornozelo. Métodos: A espessura do tendão de Aquiles e a área transversal foram medidas por meio de imagens de ultrassom da perna esquerda em 97 maratonistas amadores do sexo masculino (idade 42,0 $\pm 9,6$ anos; altura $175 \pm 6 \mathrm{~cm}$; massa corporal 73,7 $\pm 8,6 \mathrm{~kg}$ ) e 47 controles (39,9 $\pm 11,6$ anos; $176 \pm 7 \mathrm{~cm} ; 79,6 \pm 16,1 \mathrm{~kg})$. Resultados: A espessura $(4,81 \pm 0,77 \mathrm{vs} .4,60 \pm 0,66 \mathrm{~mm} ; p=$ $0,01)$ e a secção transversal $\left(60,41 \pm 14,36\right.$ vs. $\left.53,62 \pm 9,90 \mathrm{~mm}^{2} ; p<0,01\right)$ do tendão de Aquiles foram superiores nos maratonistas do que nos indivíduos não ativos. Verificou-se correlação fraca, mas significativa, entre espessura do tendão de Aquiles com os anos de experiência em corrida. Além disso, os maratonistas tiveram aumento da amplitude de movimento da articulação do tornozelo $(81,81 \pm 6,93$ vs. 77,86 $\pm 7,27$ graus; $p<0,01)$. Conclusão: Os maratonistas amadores do sexo masculino têm hipertrofia do tendão de Aquiles em comparação com indivíduos não ativos e esse aumento é mediado pela experiência em corrida. Além disso, a amplitude de movimento na flexão dorsal da articulação do tornozelo éfavorecida pelo treinamento de maratona. Nível de evidência III; Estudo retrospectivo.

Descritores: Corrida; Tendões; Tendão do calcâneo; Amplitude de movimento articular.

\section{RESUMEN}

Introducción: Este estudio buscó medir el espesory el área transversal del tendón de Aquiles (TA), y la amplitud de movimiento de la articulación del tobillo en flexión dorsal en maratonianos amateur en comparación con individuos no activos. Objetivos: Analizar la relación entre el área transversal y el grosor del tendón de Aquiles en maratonianos yedad, características antropométricas (estatura y masa corporal), hábitos de entrenamiento, experiencia en carrera, desempeño en maratón y amplitud de movimiento de la articulación del tobillo. Métodos: Fueron medidos el grosory el área transversal del tendón de Aquiles por medio de imágenes de la pierna izquierda a 97 maratonianos amateur del sexo masculino (edad 42,0 $\pm 9,6$ años; altura $175 \pm 6 \mathrm{~cm}$; masa corporal 73,7 $\pm 8,6 \mathrm{~kg}$ ), y 47 controles $(39,9 \pm 11,6$ años; $176 \pm 7 \mathrm{~cm} ; 79,6 \pm 16,1 \mathrm{~kg}$ ). Resultados: El grosor $(4,81 \pm 0,77 \mathrm{vs} .4,60 \pm 0,66 \mathrm{~mm} ; p=0,01)$ y la sección transversal $\left(60,41 \pm 14,36\right.$ vs. 53,62 $\left.\pm 9,90 \mathrm{~mm}^{2} ; p<0.01\right)$ fueron superiores en los maratonianos que en los individuos no activos. Se verificó correlación débil, aunque significativa, entre grosor del tendón de Aquiles con los años de experiencia en 
carrera. Además, los maratonianos tuvieron aumento de la amplitud de movimiento de la articulación del tobillo (81,81 $\pm 6,93$ vs. 77,86 \pm 7,27 grados; $p<0,01)$. Conclusión: Los maratonianos amateur del sexo masculino tienen hipertrofia del tendón de Aquiles en comparación con individuos no activos, y ese aumento es mediado por la experiencia en carrera. Además, la amplitud de movimiento en la flexión dorsal de la articulación del tobillo es favorecida por el entrenamiento de maratón. Nivel de evidencia III; Estudio retrospectivo.

Descriptores: Carrera; Tendones; Tendón calcáneo; Rango del movimiento articular.

\section{INTRODUCTION}

The characteristics of muscle architecture are plastic in nature and respond to exercise. ${ }^{1,2}$ Specifically, tendon physiological adaptive responses to loads, derived from exercise, have been the subject of several research projects in the last few decades. ${ }^{3,4}$ A recent systematic review argued that long-term training was associated with a larger tendon cross-sectional area, although most of the investigations on tendon adaptations are focused on resistance training while research on running training is scarcer. ${ }^{4}$

Physiological values of Achilles tendon diameters are reported to be between 4 and $6 \mathrm{~mm} .{ }^{5}$ Nevertheless, previous studies in a running context have reported that runners have a greater Achilles tendon (AT) cross-sectional area than non-runner counterparts which may indicate hypertrophy in response to the habitual load of the running exercise. - $^{-870.9}$ (4.4 Nevertheless, the differences in sample characteristics (e.g. amateur ${ }^{6,7}$ or elite runners ${ }^{8}$ electromyography and dynamometry in elite ski jumpers, distance runners, water polo players and sedentary individuals. Tendon cross-sectional area normalized to body mass $2 / 3$ was smaller in water polo players than in other athletes (patellar and Achilles tendon; -28 to -24\%) and reduced sample sizes (e.g. 6 to 10 amateurs ${ }^{6,7}$ or elite runners ${ }^{8}$ electromyography and dynamometry in elite ski jumpers, distance runners, water polo players and sedentary individuals. Tendon cross-sectional area normalized to body mass $2 / 3$ was smaller in water polo players than in other athletes (patellar and Achilles tendon; -28 to -24\%) make it difficult to draw solid conclusions. Moreover, the cross-sectional area of the Achilles tendon showed large inter-individual variability, and in amateur long distance runners, was correlated with age, body mass and height; ${ }^{9}$ hypoechoic/hyperechoic lesions, neovascularizations so establishing physiological values of the Achilles tendon in this cohort is a complex task.

Additionally, apart from tendon adaptations to increased mechanical loading in terms of a relevant functional improvement, excessive mechanical loading was considered an important factor in the etiology of tendinopathy which is characterized, among other factors, by decreased strength and flexibility. ${ }^{3}$ Reduced flexibility, and subsequent reduced range of motion in a key joint such as the ankle (e.g. reduced dorsal flexion) could be a serious disadvantage for running kinematics and increase the risk of Achilles tendon injuries. ${ }^{10}$

So, the aim of this study was to measure Achilles tendon (AT) thickness and cross-sectional area, and dorsal flexion range of motion in the ankle joint of amateur marathon runners and to compare them with non-active people. A secondary objective was to analyze the relationship between the cross-sectional area and thickness of the Achilles tendon in marathon runners and age, anthropometric characteristics (height and body mass), training habits, running experience, marathon performance and range of motion in the ankle joint. We hypothesized that long-term running training produces a thickening of the Achilles tendon modulated by running experience (years of endurance running training) and by training habits (e.g. mileage).

\section{MATERIAL AND METHODS}

\section{Subjects}

A total of 97 marathoners (age $42.0 \pm 9.6$ years; height $175 \pm 6 \mathrm{~cm}$; and body mass $73.7 \pm 8.6 \mathrm{~kg}$ ), and 47 non-active people $(39.9 \pm 11.6$ years; $176 \pm 7 \mathrm{~cm} ; 79.6 \pm 16.1 \mathrm{~kg}$ ) took part in the study. Their physical characteristics, running experience, training habits and marathon performance are presented in Table 1. Non-active people were selected from a university campus, including people who were not engaged in physical activity programs in a regular manner (e.g. $<100$ min.week ${ }^{-1}$ of moderate or vigorous physical activity). Participants were fully informed of any risks associated with the experiments before signing their informed consent to participate. The study was approved by the Camilo Jose Cela University Review Board (approval number: 15-4-2016) in accordance with the latest version of the Declaration of Helsinki.

To analyze Achilles tendon long distance running effect, a cross-sectional study was designed for comparison between marathoners and non-active people.

Each participant from the marathoners group filled out an ad hoc questionnaire about age, dorsal number, previous running experience and training habits. Then, body mass and body height were measured. After this, AT thickness was measured from ultrasound images of the left leg. Measures of the Achilles tendon were obtained while the participants were lying down on a stretcher. A C-form pillow was placed under the ankle to obtain a neutral resting position at the ankle joint. After this, $90^{\circ}$ of passive ankle flexion were conducted and maintained during the measures. A GE Logic-e ultrasound (GE Healthcare, UK) with a $12 \mathrm{~L}$ probe was employed to capture the ultrasound images in transverse section. Images were taken at the height of the lateral and medial malleolus. ${ }^{11} \mathrm{a}$ common location for injuries in runners. Twenty females ran for $10 \mathrm{~min}$ on each of three randomly ordered grades $(-6 \%, 0$ and $+6 \%$ Internal software of GE Logic-e was used to measure AT thickness. (Figure 1)

After this, participants rested in a supine position, and maximal passive ankle dorsal flexion was performed in a subtalar neutral position. A photograph was taken and recorded. On a later day, ImageJ software (National Institute of Health, U.S.A.) was employed to analyze the cross-sectional area in exported images of the GE Logic-e ultrasound, and to measure ankle dorsal flexion angle. Two experienced investigators measured the cross-sectional area twice (the intraclass correlation coefficient

Table 1. Physical characteristics, running experience, training habits and marathon performance of the marathoners $(n=97)$ and non-active people $(n=47)$.

\begin{tabular}{c|c|c}
\hline Variable (units) & Marathoners & Non-active \\
\hline Age (years) & $42.0 \pm 9.6$ & $39.9 \pm 11.6$ \\
\hline Body height $(\mathrm{cm})$ & $175 \pm 6$ & $176 \pm 7$ \\
\hline Body mass (kg) & $73.7 \pm 8.6^{*}$ & $79.6 \pm 16.1$ \\
\hline Running experience (years) & $10.9 \pm 8.5$ & - \\
\hline Training habits (running days.week ${ }^{-1}$ ) & $4.5 \pm 1.0$ & - \\
\hline Training volume (km.week $\left.{ }^{-1}\right)$ & $50.6 \pm 22.7$ & - \\
\hline Marathon performance (min) & $232.2 \pm 33.7$ & -
\end{tabular}




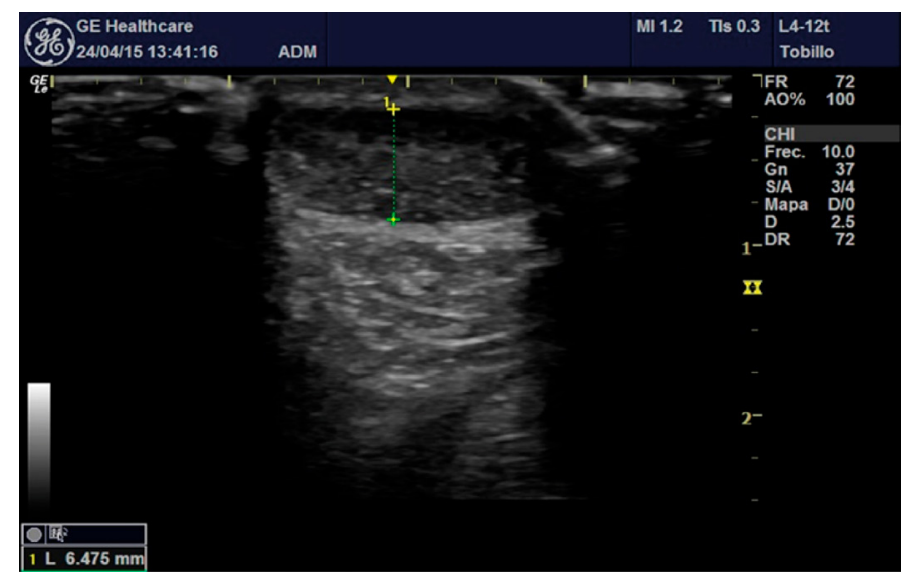

Figure 1. Measurement of cross-sectional area of the Achilles Tendon.

was 0.98). The mean of these measures was employed for calculations. Dorsiflexion was measured as the angle between the lateral midline of the lower leg (a line from the head of the fibula to the tip of the lateral malleolus) and the lateral border of the foot (a line along the rear foot and calcaneus). Similarly, two investigators (intraclass correlation coefficient: 0.97) obtained the measurements of ankle dorsiflexion and the mean was used for the statistical analysis.

Three days after the Achilles tendon cross-sectional area and AT thickness measurement, the group of marathoners took part in the Rock \& Roll Madrid Marathon (2015), wearing a race bib with a timing-chip to calculate net time (from the start to the finish line, e.g. marathon performance, Table 1). Finally, the non-active people were measured following the same protocol described for marathoners except for the marathon information.

\section{Statistical analysis}

The SPSS 19.0 statistical package (SPSS Inc., Chicago, IL, USA) was used to analyze the data. The normality of the variables was tested with the Kolmogorov-Smirnov test. All the variables presented a normal distribution. The comparison between marathoners and non-active people in Achilles tendon variables was performed using ANCOVA with body mass as covariate, as there was a positive correlation between body mass and cross sectional area in untrained human subjects ${ }^{4}$ and significant differences in mean body mass between the two groups (Table 1). Data are shown as mean \pm standard deviation and effect size (ES) was calculated for pair-wise comparisons. Partial correlation was calculated to analyze the relationship between Achilles tendon parameters and running experience and performance, eliminating the effect of age, weight and height on this correlation. The significance level was set at $p<0.05$.

\section{RESULTS}

Table 2 depicts AT thickness and cross-sectional area, and the ankle dorsal flexion of the marathoners and the non-active people group. Marathoners showed greater AT thickness (4.85 \pm 0.75 vs. $4.60 \pm 0.66$ $\mathrm{mm} ; \mathrm{ES}=0.38 ; p<0.01)$ and cross-sectional area (60.74 \pm 14.41 vs. 53.62 $\pm 9.90 \mathrm{~mm}^{2} ; \mathrm{ES}=0.72 ; p<0.01$ ) than non-active people. Moreover, range of motion in ankle dorsal flexion reached for marathoners was higher than for non-active people ( $E S=0.54 ; p=0.01$ ).

Table 2. Achilles tendon thickness and cross-sectional area, and ankle dorsal flexion of marathoners and non-active people.

\begin{tabular}{c|c|c|c}
\hline Variable (units) & Marathoners & Non-active people & $\boldsymbol{p}$ \\
\hline Achilles tendon thickness $(\mathrm{mm})$ & $4.85 \pm 0.75$ & $4.60 \pm 0.66$ & 0.001 \\
\hline Cross-sectional area $\left(\mathrm{mm}^{2}\right)$ & $60.74 \pm 14.41$ & $53.62 \pm 9.90$ & $<0.001$ \\
\hline Ankle dorsal flexion $\left(^{\circ}\right)$ & $81.75 \pm 7.02$ & $77.86 \pm 7.27$ & 0.014 \\
\hline
\end{tabular}

In non-active people, a higher cross-sectional area and thickness of the Achilles tendon was associated with greater body mass (Table 3; $p<0.001$ ) and height $(p<0.05)$, whereas body mass did not correlate with AT thickness in marathon runners $(p>0.05)$. In the marathoners, the relationship between age and both cross-sectional area and thickness of the Achilles tendon reached statistical significance but produced weak Pearson coefficients. Range of motion in ankle dorsiflexion did not correlate with age, height or body mass either in marathoners or non-active people.

In marathon runners, controlling for the effect of age, body mass and height (Table 4), years of running experience were positively but weakly related to AT thickness $(r=0.25 ; p=0.03)$. Marathon performance, number of marathons completed, average training distance and weekly training frequency did not correlate with AT thickness. Neither cross-sectional area nor ankle dorsiflexion were related to any performance or training experience in the group of marathoners.

\section{DISCUSSION}

The aim of this study was to measure AT thickness and cross-sectional area in amateur marathon runners and to compare them with non-active people. The secondary aim of the study was to analyze the relationship between the cross-sectional area and thickness of the Achilles tendon in marathoners with age, anthropometric characteristics, training habits, running experience, marathon performance and range of motion in the ankle joint. In marathoners, AT thickness has been correlated, in a weak but significant manner, with years of running experience. These data confirm that tendon hypertrophy is a slow process, and long term training was associated with a larger tendon, ${ }^{7}$ with this hypertrophy being the ultimate adjusting parameter to increased loading. ${ }^{4}$

Physiological values of Achilles tendon diameters are reported to be between 4 to $6 \mathrm{~mm}, 5$ so both mean values found in our study (e.g. marathoners and controls) are in this range, and similar to values reported in other studies with distance runners. ${ }^{12}$ While some studies involving distance runners have found greater thickness in abnormal $(5.4 \pm 0.8 \mathrm{~mm})$ respect to normal tendons $(4.7 \pm 0.5 \mathrm{~mm})$, a systematic review of the literature has indicated that tendon hypertrophy in response to the habitual loading of running had no impact on material properties. ${ }^{4}$ So, our outcomes and previous studies suggest that repetitive loading during long distance running training promotes structural changes in the Achilles tendon., ${ }^{4,13}$

Running has been associated with Achilles tendinopathy and has been described as one of the main running-related musculoskeletal injuries. ${ }^{14}$ MEDLINE (1966 to October 2011 Nevertheless, previous studies have suggested that greater tendon thickness was not related to tendinopathy. ${ }^{13,15}$ However, in Achilles tendinopathy, compromised tendon material properties are partly mitigated by tendon thickening. Hullfish et al. ${ }^{13}$ found that competitive distance runners have structurally compromised Achilles tendons despite not showing any clinical signs or symptoms of tendon injury. These findings suggest that distance running may stimulate structural changes as a protective mechanism against tendon pain and dysfunction. ${ }^{13}$ In fact, previous studies have shown that running training could propitiate a protective adaptation for running specific loading, with large cross-sectional area and tendon architecture changes. ${ }^{7,16,17}$ mean echogenicity, tendon thickness, and neovascularity were determined using well-established image processing techniques. Achilles tendon collagen was less aligned in runners compared with controls ( $28 \%$ greater

Even, Stanley et al. ${ }^{17} \mathrm{AT}$ response to cumulative load over a season is unknown. The purpose of this study was to evaluate AT response across a four-month competitive season in collegiate cross-country (XC found a positive adaptation in Achilles tendon structural integrity over a cross country training season. 
Table 3. Pearson's correlation between Achilles tendon cross sectional area, thickness and ankle dorsiflexion with age, body height and body mass.

\begin{tabular}{|c|c|c|c|c|c|c|}
\hline & \multicolumn{2}{|c|}{ Thickness (mm) } & \multicolumn{2}{|c|}{ Cross-sectional Area $\left(\mathrm{mm}^{2}\right)$} & \multicolumn{2}{|c|}{ Ankle dorsiflexion ( $\left.{ }^{\circ}\right)$} \\
\hline & Marathoners & Non-active & Marathoners & Non-active & Marathoners & Non-active \\
\hline Age (years) & $0.295^{*}$ & 0.269 & $0.280^{*}$ & 0.281 & 0.010 & 0.230 \\
\hline Body height $(\mathrm{cm})$ & $0.207^{*}$ & $0.341^{*}$ & $0.275^{*}$ & $0.407^{*}$ & -0.123 & -0.132 \\
\hline Body mass (kg) & 0.112 & $0.524^{*}$ & 0.192 & $0.490^{*}$ & -0.027 & 0.099 \\
\hline
\end{tabular}

$\left({ }^{*}\right)$ The correlation was significant at $p<0.05$.

Table 4. Relation between cross sectional area and Achilles tendon thickness with running experience, training habits and marathon performance.

\begin{tabular}{c|c|c|c}
\hline & $\begin{array}{c}\text { AT thickness } \\
(\mathbf{m m})\end{array}$ & $\begin{array}{c}\text { Cross- } \\
\text { sectional } \\
\text { area }\left(\mathbf{m m}^{\mathbf{2}}\right)\end{array}$ & $\begin{array}{c}\text { Ankle } \\
\text { dorsiflexion } \\
(\mathbf{0})\end{array}$ \\
\hline Marathon performance (min) & -0.180 & -0.104 & -0.044 \\
\hline Running experience (years) & $0.250^{*}$ & 0.054 & -0.121 \\
\hline Number of marathons completed & 0.182 & 0.173 & 0.108 \\
\hline Average training distance (km. week $^{-1}$ ) & 0.080 & 0.104 & -0.077 \\
\hline Training sessions.week ${ }^{-1}$ (number) & 0.126 & 0.020 & -0.006 \\
\hline
\end{tabular}

(*) The correlation was significant at $p<0.05$.

On the other hand, Hullfish et al. ${ }^{13}$ argued that there is a high prevalence of tendon pathology in an asymptomatic male running population with no history of Achilles tendon pain. In addition, they found in young competitive runners that years of running appear to be an associated factor of Achilles tendon pathology..$^{13}$ Our marathon runners were asymptomatic. However, we did not analyze tendon properties, such as collagen alignment, or neovascularization. More research is necessary to establish solid evidence about the relationship between long distance running and architectural properties of the Achilles tendon.

Limited ankle dorsiflexion can result in Achilles tendon pathologies. ${ }^{10}$ We have found significant differences in ankle dorsiflexion between marathoners and non-active people. Marathoners showed increased ankle range of motion ( $81.75 \pm 7.02$ vs. $77.86 \pm 7.27$ grades; $P=0.01)$ that could indicate less stiffness in this tissue. Nevertheless, other potential variables could be responsible for this difference. We cannot achieve any direct measurements of the stiffness of an isolated tendon, so this better joint flexibility could also be obtained by reduced muscle stiffness or ligament limitation and/or differences in the geometry of the articulating surfaces. ${ }^{18}$

Moreover, the outcomes of this study indicate a correlation between body mass and AT thickness and cross-sectional area in non-active people, as has previously been described in untrained people. Interestingly, in marathoners, AT thickness and cross-sectional area did not correlate with body mass.

Another variable, such as running experience, by accumulative load imposed on the Achilles tendon, may produce a stronger effect on its hypertrophy. ${ }^{6,19} 70.9$ (4.4 Milgrom et al. ${ }^{19}$ in response to endurance training exercise remains in question. We investigated the hypothesis that transition from civilian life through 6 months of elite infantry training would induce adaptive Achilles tendon hypertrophy. METHODS Seventy-two new elite infantry recruits had the cross-sectional area of their Achilles tendons measured at a point $2.5 \mathrm{~cm}$ proximal to the Achilles insertion by ultrasound before beginning elite infantry training. Measurements were repeated by the same ultrasonographer for those recruits who were still in the training program at 6 months. Prior to beginning the study the intraobserver reliability of the ultrasonographer's Achilles tendon measurements was calculated (intraclass correlation coefficient $=.96$ found an increased cross-sectional area of Achilles tendon after six month of infantry training, and the change in cross-sectional area did not correlate with subject height, weight, or prior sport history. Similar to our study, Magnusson et al. ${ }^{6}$ compared habitual runners $(\sim 80 \mathrm{~km} /$ week) with control subjects, and found a region-specific hypertrophy in response to the habitual loading of running.

Another objective was to analyze the relationship between cross-sectional area of the Achilles tendon and training habits, running experience and marathon performance. Our outcomes suggest that, in male marathon runners, there are other variables apart from running experience (weak relationship) that could explain the inter-individual variations in thickness of the Achilles tendon. Other variables such as genetic factors or biomechanical conditions that may also be correlated with marathoners AT anatomical changes. Moreover, other physical activities, such as resistance training, or other sport disciplines, ${ }^{5}$ may be responsible for these inter-individual differences. This is a first step to understanding the effect of long-distance running training on Achilles tendon properties, but we must develop future research to include other study variables for a better knowledge of hypertrophy of the Achilles tendon and its consequence on Achilles tendon properties. In addition, one limitation of this study is that we have recorded training habits by questionnaire to obtain a greater size sample. Future research should record, in a prospective and longitudinal manner, daily running mileage, for more accurate data analysis.

\section{CONCLUSION}

In summary, in this study male amateur marathoners presented hypertrophy of the Achilles tendon compared with non-active people and mediated by running experience. In addition, the load of training for marathoners was not correlated with ankle dorsiflexion. Habitual running training and loading are associated with the propitiation of an enlarged cross-sectional area. More prospective studies are necessary to elucidate the relationship between running training and Achilles tendon adaptations.

\section{ACKNOWLEDGMENTS}

The authors wish to thank the participants in this study for their invaluable contribution. In addition, we are very grateful to the Organizers of Rock'n'Roll Madrid Marathon \& $1 / 2$ for their help in setting up the investigation areas at the bib pickup area.

The study was part of the ARC\&RUN project supported by a Grant-in-aid from the Vice-Rectorate of Research and Science, at the Camilo Jose Cela University.

All authors declare no potential conflict of interest related to this article

AUTHORS' CONTRIBUTIONS: Each author made significant individual contributions to this manuscript. JJS (0000-0003-4153-5100): intellectual concept and preparation of the entire project, data collection, data analysis, statistical analysis, writing, and revision; BL: intellectual concept, data collection, and revision; JGH: data collection, data analysis, and revision; CGS: data collection, and revision; FA: data collection and revision; FJ: intellectual concept, data collection, and revision; JDC: intellectual concept and preparation of the entire project, data collection, and revision. All authors approved the final version of the manuscript. 


\section{REFERENCES}

1. Lieber RL, Friden J. Functional and clinical significance of skeletal muscle architecture. Muscle Nerve. 2000;23(11):1647-66.

2. Timmins RG, Shield AJ, Williams MD, Lorenzen C, Opar DA. Architectural adaptations of muscle to training and injury: a narrative review outlining the contributions by fascicle length, pennation angle and muscle thickness. Br J Sport Med. 2016;50(23):1467-72.

3. Bohm S, Mersmann F, Arampatzis A. Human tendon adaptation in response to mechanical loading: a systematic review and meta-analysis of exercise intervention studies on healthy adults. Sport Med Open. 2015;1(1):7.

4. Wiesinger HP, Kosters A, Muller E, Seynnes OR. Effects of Increased Loading on In Vivo Tendon Properties: A Systematic Review. Med Sci Sport Exerc. 2015;47(9):1885-95.

5. Cassel M, Carlsohn A, Frohlich K, John M, Riegels N, Mayer F. Tendon adaptation to sport-specific loading in adolescent athletes. Int J Sport Med. 2016;37(2):159-64.

6. Magnusson SP, Kjaer M. Region-specific differences in Achilles tendon cross-sectional area in runners and non-runners. Eur J Appl Physiol. 2003;90(5-6):549-53.

7. Rosager S, Aagaard P, Dyhre-Poulsen P, Neergaard K, Kjaer M, Magnusson SP. Load-displacement properties of the human triceps surae aponeurosis and tendon in runners and non-runners. Scand J Med Sci Sport. 2002;12(2):90-8.

8. Wiesinger HP, Rieder F, Kosters A, Muller E, Seynnes OR. Are sport-specific profiles of tendon stiffness and cross-sectional area determined by structural or functional integrity? PLoS One. 2016; 11(6):e0158441.

9. Hirschmuller A, Frey V, Deibert P, Konstantinidis L, Mayer F, Sudkamp N, et al. Achilles tendon power Doppler sonography in 953 long distance runners - a cross sectional study. Ultraschall Med. 2010;31(4):387-93.
10. Rabin A, Kozol Z, Finestone AS. Limited ankle dorsiflexion increases the risk for mid-portion Achilles tendinopathy in infantry recruits: a prospective cohort study. J Foot Ankle Res. 2014;7(1):48.

11. Neves KA, Johnson AW, Hunter I, Myrer JW. Does Achilles tendon cross sectional area differ after downhill, level and uphill running in trained runners? J Sport Sci Med. 2014;13(4):823-8.

12. Lieberthal K, Paterson KL, Cook J, Kiss Z, Girdwood M, Bradshaw EJ. Prevalence and factors associated with asymptomatic Achilles tendon pathology in male distance runners. Phys Ther Sport. 2019;39:64-8.

13. Hullfish TJ, Hagan KL, Casey E, Baxter JR. Achilles tendon structure differs between competitive distance runners and nonrunners despite no clinical signs or symptoms of midsubstance tendinopathy. J Appl Physiol (1985). 2018;125(2):453-8.

14. Lopes AD, Hespanhol Junior LC, Yeung SS, Costa LO. What are the main running-related musculoskeletal injuries? A Systematic Review. Sport Med. 2012;42(10):891-905.

15. Hirschmuller A, Frey V, Konstantinidis L, Baur H, Dickhuth HH, Sudkamp NP, et al. Prognostic value of achilles tendon doppler sonography in asymptomatic runners. Med Sci Sport Exerc. 2012;44(2):199-205.

16. Hagan KL, Hullfish T, Casey E, Baxter JR. Tendon structure quantified using ultrasound imaging differs based on location and training type. J Appl Physiol. 2018;125(6):1743-8.

17. Stanley LE, Lucero A, Mauntel TC, Kennedy M, Walker N, Marshall SW, et al. Achilles tendon adaptation in cross-country runners across a competitive season. Scand J Med Sci Sport. 2018;28(1):303-10.

18. Kleipool RP, Blankevoort L. The relation between geometry and function of the ankle joint complex: a biomechanical review. Knee Surg Sport Traumatol Arthrosc. 2010;18(5):618-27.

19. Milgrom Y, Milgrom C, Altaras T, Globus O, Zeltzer E, Finestone AS. Achilles Tendons Hypertrophy in Response to High Loading Training. Foot Ankle Int. 2014;35(12):1303-8. 